\title{
Career Decision Attitude and Self-determination According to Career Search Behavior of Student Athletes
}

\author{
Jong-Sik Lim, Lecturer, Dept. of Physical Education, Kunsan University, Kunsan, 54150, Korea. \\ *Chun-Ho Yang, Professor, Dept. of Marine Sports, Hanseo University, Seosan 31962, Korea, \\ healthyang@hanseo.ac.kr \\ Corresponding author
}

\begin{abstract}
This study was conducted to investigate the relationship between student athletes' career search behavior, career decision attitude, and self-determination. In this study, the survey respondents were asked to fill out a questionnaire, and the copies of the questionnaire were collected immediately after being completed by the respondents. After excluding some copies that were not sincerely filled out, 294 copies in total were used for the final analysis. The results obtained through this research process are as follows. First, a positive correlation was found between student athletes' career search behavior, career decision attitude, and self-determination. Second, career search behavior showed a statistically significant positive influence on career decision attitude. Third, career search behavior showed a statistically significant positive influence on self-determination. These results proved the justification for career search behavior before deciding on a career path. Therefore, this study concluded that it is necessary to provide career education and self-determination opportunities so that student athletes can make career decisions in the direction they desire.
\end{abstract}

Keywords: Student Athletes, Career, Behavior, Attitudes, Maturity, Determination

Received: 05.12.2020 $\quad$ Accepted: 10.01.2021 $\quad$ Published: 06.02.2021

\section{INTRODUCTION}

Although there are a wide variety of worries among teenagers living in modern society, career choice has a particularly decisive and lasting effect on an individual's life [1]. Unlike in the past, modern jobs have more important meaning as a means of self-realization to showcase and develop one's abilities and talents. Through the process of earnestly grasping one's own abilities and talents to prepare for a proper job, an individual makes a reasonable choice for a career. This also applies to high school student athletes; most of them, except for some excellent athletes, suffer from difficulties in employment as well as college admission due to poor athletic performance and academic performance $[2,3]$.

Student athletes, who have a lot of worries about their career problems at the time of entrance exams, often neglect acquiring and developing the skills and studies necessary for education and professional life because they spend substantial amounts of time preparing for intense competition $[4,5,6]$. In particular, high school student athletes can lack the basic knowledge necessary for a minimal social life due to factors such as not attending normal classes due to their college or career paths as well as having inexperienced relationships with peers. If their college and career paths progress normally, they may be prepared for future career decisions, but most student athletes are only making vague decisions about their careers.

In fact, thousands of student athletes are dropping out in the time that other athletes are becoming famous and successful [7]. Therefore, it can be said that this represents a time when research related to careers is needed in case student athletes drop out.

Currently, career theories are classified in various ways, and related research is actively underway. From the point of view of career, a person's life is not determined at any one moment, but is instead formed by properly achieving some developmental task over a long period of time. Among them, this study researched career search behavior, career decision attitude, and self-determination, and it is expected that providing helpful data to the careers of student athletes will help students' career decision making.

Career search behavior includes obtaining the qualifications necessary to get a job, collecting job information, equipping oneself with the tools necessary to achieve a career goal, and other activities that involve investing time and effort to achieve a set career goal, which is not simply a cognitive or attituderelated dimension regarding one's own career, but a practical, concrete action [8]. As such, aside from the most basic and specific behavior, many student athletes practice inadequate career search behavior. 
Student athletes preparing for future careers have a lot of concerns about their careers, but they do not know what to do about career preparation [9]. Student athletes experience more difficulties preparing for a career because they have more trouble with schoolmates and school life than ordinary students. This can also be seen through prior research $[10,11]$ on student athletes which indicates that a significant number of students are feeling more stress due to future problems, such as employment and career problems. What is more problematic is that they show substantial interest and concern regarding future problems, but they do not actually show specific search behaviors.

Career decisions are an important issue for student athletes. Depending on the decisions a student makes about his or her career, their lifestyle as well as their values and attitudes may change. The career decision attitude of a student athlete includes considerations of their career decision-making process, career preparation, personal characteristics, immediate development tasks, and decision-making situation, and these are to understand the personal variables that affect the career search and career attitudes of student athletes [12]. This problem of career decision is not limited to the individual, but can also have a great influence on the developmental aspects of youth. For student athletes, career problems, like issues with this turning point in life, are raised as problems to be seriously considered at this point. In addition, one of the important factors that can affect the career problems of student athletes is selfdetermination. The level of self-determination depends on how much an individual perceives autonomy over their actions [13]. Therefore, raising the self-determination level of student athletes can be said to increase the search behavior and decision attitude for careers.

Therefore, this study aims to provide basic data necessary for discovering and developing the possibilities the students possess by identifying the relationship between career search behavior, career decision attitude, and self-determination in high school student athletes.

\section{Methods}

\subsection{Subjects}

Table 1 General characteristics of subjects

\begin{tabular}{llll}
\hline Variable & Classification & Frequency (n) & Percentage (\%) \\
\hline \multirow{2}{*}{ Gender } & Male & 171 & 58.2 \\
& Female & 123 & 41.8 \\
\multirow{5}{*}{ School year } & 1 $^{\text {st }}$ grade & 93 & 31.6 \\
& 2 $^{\text {nd }}$ grade & 95 & 32.3 \\
& 3rd $^{\text {grade }}$ & 106 & 36.1 \\
\multirow{5}{*}{ Sports category } & Individual event & 97 & 33.0 \\
& Man-to-man event & 84 & 28.6 \\
& Team event & 113 & 38.4 \\
\multirow{5}{*}{ Career plan } & University entrance & 156 & 53.1 \\
& Pro team & 34 & 11.6 \\
& General employment & 45 & 15.3 \\
& Employment preparation & 59 & 20.0 \\
\hline
\end{tabular}

The subjects of this study were high school student athletes enrolled in the Korean Sport \& Olympic Committee in 2020. For sampling, a convenience sampling method was used to identify 300 high school student athletes. The survey tool used a questionnaire, and the questionnaire was answered by the selfevaluation method. In total, 294 points of data were used for the final analysis after excluding questionnaires that did not meet the criteria of the study. [Table 1] lists the general characteristics of the study subjects.

\subsection{Tools}

\subsubsection{Career search behavior}

The tool used in this study to measure the survey's career search behavior scale was the career search behavior test developed by [14], with modifications to suit the needs of the study. Career search 
behavior consisted of preparation activities (four items), counseling activities (four items), and search activities (four items). The measurement method of each item consisted of a Likert scale measured among 'Strongly disagree' (1 point), 'Disagree' (2 points), 'Neutral' (3 points), 'Agree' (4 points), and 'Strongly agree' (5 points).

\subsubsection{Career decision attitude}

The tool used in this study to measure the survey's career decision attitude scale was the career decision test developed by [15] and modified to suit the needs of the study. Career decision attitude consisted of career readiness (three items), career maturity (three items), and career decidedness (three items). The measurement method of each item consisted of a Likert scale measured among 'Strongly disagree' (1 point), 'Disagree' (2 points), 'Neutral' (3 points), 'Agree' (4 points), and 'Strongly agree' (5 points).

\subsubsection{Self-determination}

The tool used in this study to measure the survey's self-determination scale was the high school student self-determination measurement survey designed by [16] with modifications to suit the needs of the study. Self-determination consisted of autonomy (four items), competence (four items), and relationship (four items). The measurement method of each item consisted of a Likert scale measured among 'Strongly disagree' (1 point), 'Disagree' (2 points), 'Neutral' (3 points), 'Agree' (4 points), and 'Strongly agree' (5 points).

\subsection{Validity and Reliability}

Principal component analysis of exploratory factor analysis was used to verify the validity of the research tool. For simplification of the factor structure, varimax was used among the orthogonal rotation methods. The common factor extraction method was based on an Eigenvalue of 1.0 or higher, and the factor loading was limited to items of .50 or higher. Cronbach's $\alpha$ coefficient according to the internal consistency criteria was used to verify the reliability of the survey tool.

\subsubsection{Career search behavior}

Table 2 Results of validity and reliability analysis of career search behavior

\begin{tabular}{llccc}
\hline Q No. & Readiness activities & Counseling activities & Search activities & $\mathrm{h}^{2}$ \\
\hline Q 07 & $\mathbf{. 8 7 3}$ & .225 & -.015 & .612 \\
Q 06 & .854 & .185 & -.014 & .695 \\
Q 05 & .837 & .194 & .086 & .790 \\
Q 08 & .735 & .096 & .152 & .604 \\
Q 03 & .159 & .871 & .078 & .745 \\
Q 02 & .778 & .113 & .763 \\
Q 01 & .761 & .135 & .814 \\
Q 04 & .122 & .753 & .120 & .573 \\
Q 11 & .152 & .266 & .760 & .543 \\
Q 10 & .142 & .757 & .615 \\
Q 09 & .030 & -.060 & .734 & .649 \\
Q 12 & .146 & 2.112 & .724 & .525 \\
\hline Eigenvalue & .016 & 17.597 & 1.511 & \\
Variance $\%$ & .017 & 53.457 & 12.591 & \\
Cumulative $\%$ & 35.860 & .894 & 66.048 & \\
\hline Reliability & .86 .860 & & .850 &
\end{tabular}

According to [Table 2], the Bartlett unit matrix of career search behavior was 1487.069, its significant probability was .001, and its KMO index was .830, and the selection of variables was considered to be appropriate. For career search behavior, three factors were extracted as a result of the factor analysis of 12 items, and it was found that about $66.0 \%$ of the total variance was explained by these factors. The loading of career activities, a sub-variables of career search behavior, was career readiness activities .735 .873. The loading of counseling activities was .753 .871 and the loading of 
search activities was .724 .760. The reliability values of career search behavior were career readiness activities .867, counseling activities .894, and search activities .850 , and they were found to be relatively reliable.

\subsubsection{Career decision attitude}

According to [Table 3], the Bartlett unit matrix of career decision attitude was 834.794, its significant probability was .001, and its KMO index was .758, and the selection of variables was found to be appropriate. For career decision attitude, three factors were extracted as a result of the factor analysis of nine items. The loading of preparation activities, a sub-variable of career decision attitude, was career readiness attitudes .738 .840. The loading of career maturity was .767 .856 and the loading of career decidedness was .633 .859. The reliability values of career decision attitude were readiness activities .849 , career maturity .846 , and career decidedness .850 , and these were found to be relatively reliable.

Table 3 Results of validity and reliability analysis of career decision attitude

\begin{tabular}{llcll}
\hline Q No. & Career readiness & Career maturity & Career decidedness & $\mathrm{h}^{2}$ \\
\hline Q 06 & $\mathbf{. 8 4 0}$ & .088 & .063 & .568 \\
Q 05 &. $\mathbf{7 9 2}$ & .125 & .244 & .703 \\
Q 04 &. $\mathbf{7 3 8}$ & .103 & .112 & .718 \\
Q 02 & .203 & .856 & .001 & .574 \\
Q 01 & .161 & .850 & .123 & .754 \\
Q 03 & -.025 & .767 & .254 & .627 \\
Q 08 & -.049 & .121 & .859 & .763 \\
Q 07 & .290 & .053 & .698 & .775 \\
Q 09 & .383 & .282 & .633 & .653 \\
\hline Eigenvalue & 3.437 & 1.525 & 1.173 & \\
Variance $\%$ & 37.189 & 16.941 & 13.036 & \\
Cumulative $\%$ & 38.189 & 55.130 & 68.167 & .850 \\
\hline Reliability & .849 & .846 &
\end{tabular}

\subsubsection{Self-determination}

Table 4 Results of validity and reliability analysis of self-determination

\begin{tabular}{lllll}
\hline Q No. & Autonomy & Competence & Relationship & $\mathrm{h}^{2}$ \\
\hline Q 07 & $\mathbf{. 8 6 4}$ & .132 & .004 & .530 \\
Q 06 & $\mathbf{. 8 0 9}$ & .018 & -.012 & .600 \\
Q 05 & $\mathbf{. 7 8 8}$ & .241 & -.007 & .646 \\
Q 08 & .780 & .048 & .201 & .560 \\
Q 03 & -.011 &. $\mathbf{8 0 3}$ & -.033 & .679 \\
Q 02 & -.005 &. $\mathbf{7 4 4}$ & -.078 & .765 \\
Q 01 & .216 &. $\mathbf{7 4 2}$ & .054 & .652 \\
Q 04 & .241 & .671 & .148 & .656 \\
Q 11 & -.025 & .056 &. $\mathbf{7 7 3}$ & .561 \\
Q 10 & -.023 & .040 & .773 & .374 \\
Q 09 & .029 & -.014 & .747 & .598 \\
Q 12 & .163 & 2.115 & .590 & .601 \\
\hline Eigenvalue & 3.303 & 17.622 & 1.804 & \\
Variance $\%$ & 27.523 & 45.145 & 60.182 & .851 \\
Cumulative $\%$ & 27.523 & .850 & &
\end{tabular}

According to [Table 4], the Bartlett unit matrix of self-determination was 1038.797, its significant probability was .001, and its KMO index was .761, and the selection of variables was considered to be appropriate. For self-determination, three factors were extracted as a result of the factor analysis of 12 items, and it was found that about $60.2 \%$ of the total variance was explained by these factors. The loading of autonomy, a sub-variable of self-determination, was found to be .780 .864. The loading of competence was .671 .803 and the loading of relationship was .590 .773. The reliability values of selfdetermination were autonomy .860 , competence .850 , and relationship .851 , and these were found to 
be relatively reliable.

\subsection{Data Processing}

SPSS (ver 21.0) statistics program was used to analyze the collected data. The data collected according to the purpose of the study consisted of 294 copies of the questionnaire after excluding the surveys determined not to be appropriate for the study. The collected data was subjected to frequency analysis, exploratory factor analysis, and reliability verification using SPSS 21.0 to confirm the normal distribution, validity, and reliability of the data. Correlation analysis was performed to determine the relationships between variables, and multiple regression analysis was performed to obtain the causal relationships between variables. Here, the significance level was set to $\alpha=.05$.

\section{Results}

3.1. Correlation Between Career Search Behavior, Career Decision Attitude, and Self-determination in Student Athletes

Table 5 Results of correlation between career search behavior and career decision attitude and selfdetermination

\begin{tabular}{llllccccrr}
\hline Variable & $\mathrm{A}$ & $\mathrm{B}$ & $\mathrm{C}$ & $\mathrm{D}$ & $\mathrm{E}$ & $\mathrm{F}$ & $\mathrm{G}$ & $\mathrm{H}$ & $\mathrm{I}$ \\
\hline Career readiness & - & & & & & & & & \\
Counseling activities & .089 & - & & & & & & \\
Search activities & $.430^{* * *}$ & $.252^{* * *}$ & - & & & & & \\
Career readiness & $.430^{* * *}$ & $.195^{* * *}$ & $.559^{* * *}$ & - & & & & \\
Career maturity & $.512^{* * *}$ & $.205^{* * *}$ & $.632^{* * *}$ & $.611^{* * *}$ & - & & & \\
Career decidedness & $.425^{* * *}$ & $.184^{* *}$ & $.515^{* * *}$ & $.640^{* * *}$ & $.594^{* * *}$ & - & & \\
Autonomy & $.385^{* * *}$ & $.173^{* *}$ & $.437^{* * *}$ & $.504^{* * *}$ & $.606^{* * *}$ & $.514^{* * *}$ & - & & \\
Competence & $.326^{* * *}$ & $.258^{* * *}$ & $.595^{* * *}$ & $.515^{* * *}$ & $.608^{* * *}$ & $.531^{* * *}$ & $.414^{* * *}$ & & - \\
Relationship & $.393^{* * *}$ & $.159^{* *}$ & $.618^{* * *}$ & $.530^{* * *}$ & $.656^{* * *}$ & $.506^{* * *}$ & $.375^{* * *}$ & $.720^{* * *}$ & - \\
\hline
\end{tabular}

${ }^{* * *} p<.001,{ }^{* *} p<.01$

[Table 5] shows the correlation between career search behavior, career decision attitude, and selfdetermination. Specifically, preparation activities showed positive correlations in search activities $(\mathrm{r}=.430)$, career readiness $(\mathrm{r}=.430)$, career maturity $(\mathrm{r}=.430)$, career decidedness $(\mathrm{r}=.425)$, autonomy $(\mathrm{r}=.385)$, competence $(\mathrm{r}=.326)$, and relationship $(\mathrm{r}=.393)$. Counseling activities showed positive correlations in search activities $(\mathrm{r}=.252)$, career readiness $(\mathrm{r}=.195)$, career maturity $(\mathrm{r}=.205)$, career decidedness ( $\mathrm{r}=.184)$, autonomy $(\mathrm{r}=.173)$, competence $(\mathrm{r}=.258)$, and relationship $(\mathrm{r}=.159)$. Search activities showed positive correlations in career readiness $(\mathrm{r}=.559)$, career maturity $(\mathrm{r}=.632)$, career decidedness ( $\mathrm{r}=.515)$, autonomy ( $\mathrm{r}=.437)$, competence $(\mathrm{r}=.595)$, and relationship ( $\mathrm{r}=.5618)$.

\subsection{Career Search Behavior and Career Decision Attitude of Student Athletes}

\subsubsection{Career search behavior and career readiness}

Table 6 Relationship between career search behavior and career readiness

\begin{tabular}{|c|c|c|c|c|c|c|}
\hline & B & SE & $\beta$ & $t$ & $\mathrm{e}^{\text {Toleranc }}$ & VIF \\
\hline (Constant) & .760 & .254 & & $2.990^{* *}$ & & \\
\hline Career readiness & .256 & .057 & .234 & $4.492^{* * *}$ & 815 & 1.227 \\
\hline Counseling activities & .058 & .045 & .062 & 1.280 & .936 & 1.069 \\
\hline Search activities & .500 & .061 & .442 & $8.257^{* * *}$ & .769 & 1.301 \\
\hline
\end{tabular}

$\mathrm{F}=54.318^{* * *}, \mathrm{R}^{2}=.360$, Corrected $\mathrm{R}^{2}=.353$

${ }^{* * *} p<.001,{ }^{* *} p<.01$

As presented in [Table 6], career search behavior had a statistically significant effect on career readiness $(\mathrm{F}=54.318, \mathrm{p}<.001)$, and its explanatory power was about $36.0 \%\left(\mathrm{R}^{2}=.360\right)$ of the total variance. In terms of the Beta value of the relative influence of career search behavior on career readiness, positive influences were found in preparation activities $(\beta=.234, \mathrm{p}<.001)$ and search activities $(\beta=.442, \mathrm{p}<.001)$. 


\subsubsection{Career search behavior and career maturity}

Table 7 Relationship between career search behavior and career maturity

\begin{tabular}{lllllll}
\hline & $\mathrm{B}$ & $\mathrm{SE}$ & $\beta$ & $t$ & Tolerance & VIF \\
\hline \multicolumn{1}{c}{ (Constant) } & 1.332 & .177 & & $7.527^{* * *}$ & & \\
Career readiness & .248 & .040 & .296 & $6.267^{* * *}$ & .815 & 1.227 \\
Counseling activities & .039 & .031 & .055 & 1.239 & .936 & 1.069 \\
Search activities & .425 & .042 & .491 & $10.094^{* * *}$ & .769 & 1.301 \\
\hline
\end{tabular}

$\mathrm{F}=86.709 * * *, \mathrm{R}^{2}=.473$, Corrected $\mathrm{R}^{2}=.467$

$* * * p<.001$

As shown in [Table 7], career preparation behavior had a statistically significant effect on career maturity $(\mathrm{F}=86.709, \mathrm{p}<.001)$, and its explanatory power was about $47.3 \%\left(\mathrm{R}^{2}=.473\right)$ of the total variance. Regarding the Beta value of the relative influence of career search behavior on career maturity, positive influences were found in preparation activities $(\beta=.296, \mathrm{p}<.001)$ and search activities $(\beta=.491, \mathrm{p}<.001)$.

\subsubsection{Career search behavior and career decidedness}

Table 8 Relationship between career search behavior and career decidedness

\begin{tabular}{|c|c|c|c|c|c|c|}
\hline & $\mathrm{B}$ & SE & $\beta$ & $t$ & Tolerance & VIF \\
\hline (Constant) & .744 & .284 & & $2.619^{* *}$ & & \\
\hline Career readiness & .298 & .064 & .251 & $4.677^{* * *}$ & .815 & 1.227 \\
\hline Counseling activities & .063 & .050 & .063 & 1.251 & .936 & 1.069 \\
\hline Search activities & .479 & .068 & .391 & $7.086^{* * *}$ & .769 & 1.301 \\
\hline \multicolumn{7}{|c|}{$\mathrm{F}=45.432^{* * *}, \mathrm{R}^{2}=.320$, Corrected $\mathrm{R}^{2}=.313$} \\
\hline
\end{tabular}

As listed in [Table 8], career preparation behavior had a statistically significant effect on career decidedness $(\mathrm{F}=45.432, \mathrm{p}<.001)$, and its explanatory power was about $47.3 \%\left(\mathrm{R}^{2}=.473\right)$ of the total variance. For the Beta value of the relative influence of career search behavior on career decidedness, positive influences were found in preparation activities $(\beta=.251, p<.001)$ and search activities $(\beta=.391$, $\mathrm{p}<.001)$.

\subsection{Career Search Behavior and Self-determination of Student Athletes}

\subsubsection{Career search behavior and autonomy}

Table 9 Relationship between career search behavior and autonomy

\begin{tabular}{lllllll}
\hline \multicolumn{1}{c}{} & $\mathrm{B}$ & $\mathrm{SE}$ & $\beta$ & $t$ & Tolerance & VIF \\
\hline \multicolumn{1}{c}{ (Constant) } & 1.421 & .267 & & $5.322^{* * *}$ & & \\
Career readiness & .257 & .060 & .243 & $4.290^{* * *}$ & .815 & 1.227 \\
Counseling activities & .065 & .047 & .072 & 1.370 & .936 & 1.069 \\
Search activities & .343 & .064 & .315 & $5.406^{* * *}$ & .769 & 1.301 \\
\hline
\end{tabular}

Search activities $.343 \quad .06$

$* * * p<.001, * * p<.01$

As shown in [Table 9], career search behavior had a statistically significant effect on autonomy $(\mathrm{F}=31.135, \mathrm{p}<.001)$, and its explanatory power was about $24.4 \%\left(\mathrm{R}^{2}=.244\right)$ of the total variance. Regarding the Beta value of the relative influence of career search behavior on autonomy, positive influences were found in preparation activities $(\beta=.243, \mathrm{p}<.001)$ and search activities $(\beta=.315, \mathrm{p}<.001)$.

\subsubsection{Career search behavior and competence}

Table 10 Relationship between career search behavior and competence 


\begin{tabular}{lllllll}
\hline & $\mathrm{B}$ & $\mathrm{SE}$ & $\beta$ & $t$ & Tolerance & VIF \\
\hline \multicolumn{1}{c}{ (Constant) } & 1.095 & .232 & & $4.725^{* * *}$ & & \\
Career readiness & .090 & .052 & .089 & 1.730 & .815 & 1.227 \\
Counseling activities & .100 & .041 & .118 & $2.444^{*}$ & .936 & 1.069 \\
Search activities & .547 & .055 & .527 & $9.927^{* * *}$ & .769 & 1.301 \\
\hline \multicolumn{2}{c}{$\mathrm{F}=57.387^{* * *}, \mathrm{R}^{2}=.373$, Corrected $\mathrm{R}^{2}=.366$} & & & & \\
\hline$* * * p<.001,{ }^{*} p<.05$ & & &
\end{tabular}

As presented in [Table 10], career search behavior had a statistically significant effect on competence $(\mathrm{F}=57.387, \mathrm{p}<.001)$, and its explanatory power was about $37.3 \%\left(\mathrm{R}^{2}=.373\right)$ of the total variance. In terms of the Beta value of the relative influence of career search behavior on competence, positive influences were found in counseling activities $(\beta=.118, p<.05)$ and search activities $(\beta=.527, p<.001)$.

\subsubsection{Career search behavior and relationship}

As listed in [Table 11], career search behavior had a statistically significant effect on relationship $(\mathrm{F}=64.851, \mathrm{p}<.001)$, and its explanatory power was about $40.2 \%\left(\mathrm{R}^{2}=.402\right)$ of the total variance. For the Beta value of the relative influence of career search behavior on relationship, positive influences were found in preparation activities $(\beta=.156, \mathrm{p}<.01)$ and search activities $(\beta=.549, \mathrm{p}<.001)$.

Table 11 Relationship between career search behavior and relationship

\begin{tabular}{lllllll}
\hline & $\mathrm{B}$ & $\mathrm{SE}$ & $\beta$ & $t$ & Tolerance & VIF \\
\hline \multicolumn{1}{c}{ (Constant) } & 1.241 & .216 & & $5.750^{* * *}$ & & \\
Career readiness & .150 & .048 & .156 & $3.109^{* *}$ & .815 & 1.227 \\
Counseling activities & .006 & .038 & .007 & .147 & .936 & 1.069 \\
Search activities & .544 & .051 & .549 & $10.590^{* * *}$ & .769 & 1.301 \\
\hline
\end{tabular}

$\mathrm{F}=64.851^{* * *}, \mathrm{R}^{2}=.402$, Corrected $\mathrm{R}^{2}=.395$

$* * * p<.001, * * p<.01$

\section{Discussion}

This study was conducted to investigate the relationship between the career search behavior, career decision attitude, and self-determination of student athletes, and the discussion of the research results is as follows.

In this study, a positive correlation was found between student athletes' career search behavior, career decision attitude, and self-determination. A multiple regression analysis was conducted to examine this in detail, and career search behavior was found to have significant positive and partial influences in career readiness, career maturity, and career decidedness. In addition, career search behavior showed significant positive and partial influences in autonomy, competence, and relationship.

These results are consistent with those of a study on the positive correlation and significant impact between career search behavior and career decision level of college athletes [17] and those of a study that found that there was a significant relationship between career search behavior and career decision level among physical education examinees [18]. In addition, reports indicating that people with high selfefficacy in career decision making also have high career maturity $[3,19]$ further support the results of this study. These results suggest that it is necessary to develop strategies to deal with the career preparation results of high school student athletes and to make behavioral efforts to avoid negative results.

In general, regarding work, an individual goes through a series of processes of exploring his or her career options while planning and preparing for it. In the end, a career decision is made through a complicated process, and these results show that career preparation behavior has a positive effect on the clear purpose of preparation and individual independence. One of the most important developmental tasks in the career decision-making process is the search for careers to determine career direction and career choice [2,20]. One of the most important ways to increase the career decision attitude of high school student athletes is to stress the importance of preparing for careers based on counseling and the exploration of career paths. A desirable career decision attitude can be said to be the result of career design and planning over a long time through career education. It is important to establish a career decision attitude to reasonably decide on a career in this decisive time.

The results of this study showed that a positive correlation and a significant positive influence were statistically identified for self-determination according to career search behavior. These results prove 
that career search behavior is an explanatory factor for self-determination. That is, the higher the selfdetermination, the higher the preparation activities, counseling activities, and search activities. Therefore, it is necessary to increase self-determination to improve career search behavior. It is important to establish social and environmental conditions to increase self-determination because the levels of selfdetermination and career search behavior vary depending on how much an individual perceives autonomy over his or her behavior. In addition, increasing the level of self-determination by maintaining emotional support and positive relationships with others is a way to ensure that individual student athletes can feel competence to respect their autonomous judgments when participating in sports.

For high school student athletes, the reasons for not being able to make decisions about their career include a lack of understanding about themselves, lack of information about careers, and fear of choosing. Therefore, it is important to increase the self-determination of student athletes. This is because the higher the self-determination of high school student athletes, the more self-understanding, self-confidence, certainty about the future, and perceptions of career and career information, thereby enabling career search behavior. The results of this study indicate that it is necessary to establish attitudes that determine career paths and self-directed decisions, such as behaviors for self-discovery and career exploration of student athletes, a selection of majors suitable for employment and aptitude, and progression to college, through career decision attitude and self-determination according to the career search behavior of student athletes.

\section{Conclusion}

This study was conducted to investigate the relationship between student athletes' career search behavior, career decision attitude, and self-determination, and the conclusions obtained through this research process are as follows.

First, a positive correlation was found between student athletes' career search behavior, career decision attitude, and self-determination. Second, career search behavior showed a statistically significant positive influence on career decision attitude. Third, career search behavior showed a statistically significant positive influence on self-determination.

These results prove the justification for career search behavior before deciding on a career path. Therefore, this study finds that it is necessary to provide career education and self-determination opportunities so that student athletes can make career decisions in the direction they desire.

\section{Acknowledgment}

This study was from the 2020 Academic Research Support Project of Hanseo University.

\section{References}

[1] Kim, J. U., \& Kang, J. I. The Effect of Perceived Parenting Attitudes by Teenagers and Their Psychological Separation on Career Decision-Making Level. The Journal of Career Educational Research. 2009; 22(3): 121-135.

[2] Lim, J.S., Oh, Y.P \& Yang, C.H. Effects of University Student Players' Achievement Goal Orientations on Career Maturity and Career Exploratory Behaviors. The Korean Journal of Sport. 2016; 14(3): 55-65.

[3] Lim, J.S., \& Yang, C.H. Relationships between Marine Sports Participants' Exercise Adherence and Interpersonal Orientation and Their Exercise Desire. The Korean Journal of Sport. 2014; 12(3): 325336.

[4] Park, J.Y. The Influence of Youth's Resilience and Social Support On Self-Efficacy Regarding Career Decision-Making and Career Attitude Maturity. The Korean Society Of School Social Work. 2018; 42: 187-208.

[5] Moon, H. J., \& Lee, S. H. Effects of Athletic Experience Characteristics and Self-Management on the Level of Career Decision Making among Highschool Student Athletes. Journal of Sport and Leisure Studies. 2010; 42: 559-570.

[6] Lee, J.C. Theoretical Study and Comparison Analysis of Research Results on the Career Decision SelfEfficacy of University Students. Journal of Employment and Career. 2013; 3(1): 49-66.

[7] Yim, Y. S., Han, M. S., \& Kim, J. S. The Path-Analysis of Student Athletes` Drop-Out. Korean Journal of Sport Science. 2014; 25(3): 450-466.

[8] Kim, B. W. The Relationship of Resilience, Career Attitude Maturity and Career Preparation Behavior of College Woman. Career Education Research. 2010; 23(4): 93-111.[9] Kim, M. J. Effect of Career barrier on College Students' Career Preparation Behavior : The Mediating Effect of Career SelfRegulation. The Journal of Career Education Research. 2016; 29(2): 77-94.

[10] Kim, H. S. \& Kim, O. H. The study on the path model of support level, stress, self-concept and career 
development. The Journal of Career Education Research. 2008; 21(1): 89-107.

[11] Shon, S. J., \& Kim, B. J. The Relationship on the Amateur and Professional Athletes and Social Relationship Network, Career Exploration Behavior. Korean journal of physical education. 2005; 44(6): 237-246.

[12] Kim, Y. H., Kim, K. E., \& Choi, J. H. Career decision-making styles and career maturity amongst Korean undergraduate students. Journal of the Korea Academia-Industrial cooperation Society. 2011; 12(3): 1223-1233.

[13] Lee, J. H. The Relationship of Career Identity and Career Preparation Behavior of University Students: the mediating Effects of Self-determination and Career Maturity. The Journal of Learner-Centered Curriculum and Instruction. 2013; 13(3): 133-154.

[14] Choi, D. S. Relationship between career exploration behavior and motivational factors and attachment of undergraduate students. Unpublished doctor Dissertation. Seoul National University; 2003.

[15] Osipow, S. H. Assessing career indecision. Journal of Vocational Behavior. 1999; 55: 147-154.

[16] Lee, M. H., \& Kim, A. Y.. Development and Construct Validation of the Basic Psychological Needs Scale for Korean Adolescents: Based on the Self-Determination Theory. The Korean Journal of Social and Personality Psychology. 2008; 22(4): 157-174.

[17] Yoo, D. H., Yeo, I. S., \& Ahn, B. W. The influence of Life-style on Career Decision Level and Career Preparation Behavior in the Collegiate Athletes. Journal of Sport and Leisure Studies. 2011; 46(1): 773-784.

[18] Kim, Y. J., Yang, W. Y., \& Cha, Y. S. The Effect of Perceived Career Barriers on The Career Decision Level of The Examinee of Physical Education Department. The Korea Journal of Sport. 2012; 10(2): 221-230.

[19] Jo, H. I., Lee, Y. J., Oh, S. H., \& Kim, K. M. The Influence of Exercise Stress on Careers Decision-Making Self-Efficacy, and Vocational Maturity of High School Bowling Players. Korean journal of sports science. 2012; 21(2): 159-173.

[20] Kim, K. W. Career Decision-Making Self-Efficacy and Career Exploration Behavior by Sports Career of Student Boxers. The official journal of the korean association of certified exercise professionals. 2016; 18(3): 35-42. 